\title{
The extent of soil organic carbon and total nitrogen in forest fragments of the central highlands of Ethiopia
}

\author{
Terefe Tolessa $^{1 *}$ (D) and Feyera Senbeta ${ }^{2}$
}

\begin{abstract}
Background: Deforestation and degradation are currently affecting the ecosystem services of forests. Among the ecosystem services affected by deforestation and degradation are the amount of soil organic carbon (SOC) and total nitrogen (TN) stored in forest soils which have greater impacts in global climate change. This study aimed at examining the amount of SOC and TN in the forest fragments which were separated from the continuous tracts of forests of Jibat and Chillimo through fragmentation processes over four decades.

Methods: We have sampled soils from 15 forest fragments of Chillimo and Jibat in the central highlands of Ethiopia. The soil samples obtained in two separate soil depths $(0-30$ and $30-60 \mathrm{~cm})$ were bulked, dried, and sieved for analysis.

Results: Our results have shown that the two sites (Jibat and Chillimo forest fragments) differed in their SOC and TN contents. While the values for Jibat were found to be $29.89 \mathrm{Mg} / \mathrm{ha}$ of SOC and $2.84 \mathrm{Mg} / \mathrm{ha}$ for TN, it was 14 . $06 \mathrm{Mg} / \mathrm{ha}$ of SOC and $1.40 \mathrm{Mg} / \mathrm{ha}$ for TN for Chillimo. When all forest fragment soil samples were bulked together, Jibat site had twice the value of SOC and TN than Chillimo. When disaggregated on the basis of each fragments, there existed differences in SOC (1.86 Mg/ha and $42.15 \mathrm{Mg} / \mathrm{ha})$ and TN (0.24 Mg/ha and 4.23 Mg/ha) values. Among the forest fragments, fragment four $\left(\mathrm{F}_{4}\right)$ had the highest Relative Soil Improvement Index (RSII) value of 3826.82\% and fragment fifteen $\left(F_{15}\right)$ had the lowest RSII value (726.87\%) which indicated that the former had a better quality of soil properties than the latter.

Conclusion: SOC and TN differed across sampled fragments and sites. Variations in soil properties are the reflections of inherent soil parent material, aboveground vegetation, human interferences, and other physical factors. Such differences could be very important for identifying intervention measures for restoration and enhancing ecosystem services of those fragments.
\end{abstract}

Keywords: Forest fragments, Soil organic carbon, Total nitrogen, Ecosystem services, Central highland

\section{Introduction}

Deforestation and fragmentation are the two most important factors affecting the forest thereby reducing the ecosystem services such as soil organic carbon (SOC) and total nitrogen (TN) regulation accumulation (Echeverria et al. 2006; Demessie et al. 2011; Gelaw et al. 2014; Tesfaye et al. 2016). The underlying causes include population increase that further resulted in a number of

\footnotetext{
* Correspondence: tertol2000@yahoo.com

'Institute of Cooperatives and Development Studies, Ambo University, Ambo, Ethiopia

Full list of author information is available at the end of the article
}

proximate causes such as demand for forest products, land for crop production, and settlement. It is a common phenomenon to find fragmented forests in the matrix of human-modified landscapes in the central highlands of Ethiopia where agriculture is the dominant livelihood activity. These forest fragments are found on steep slopes, inaccessible areas, and sacred groves (Bennett and Saunders 2010) where settlement and crop cultivation are usually not possible because of the inherent low level fertility of the land and cultural and religious issues related to the forests (Wassie et al. 2009).

(c) The Author(s). 2018 Open Access This article is distributed under the terms of the Creative Commons Attribution 4.0 International License (http://creativecommons.org/licenses/by/4.0/), which permits unrestricted use, distribution, and 
Several factors that result in fragmentation of forests such as grazing can reduce soil organic carbon, total nitrogen, and soil pH (Demessie et al. 2011; Cardelús et al. 2013; Dingpeng et al. 2014). This can be attributed to the removal of aboveground biomass due to grazing, logging, firewood collection, and deterioration of soil physical parameters. The changes in SOC and $\mathrm{TN}$ vary across disturbance regime, soil layers, and locations due to climatic, edaphic, biological, land management practices, vegetation cover, aspect, and topography (Moraes et al. 1995; Batjes 1996; Lemenih and Itanna 2004; Vágen et al. 2005; Yimer et al. 2006; Jiménez et al. 2007; Navarrete and Tsutsuki 2008; Shrestha and Singh 2008; Sakai et al. 2010; Demessie et al. 2011; Gamfeldt et al. 2013; Peng et al. 2013; Beniston et al. 2014; Habtemicael et al. 2014; Yimer et al. 2015; Mathew et al. 2016; Gurmessa et al. 2016; Birhane et al. 2017), and such changes affect the overall productivity of the ecosystems (Chen et al. 2015). Understanding and incorporating such heterogeneity and spatial distribution characteristics can improve the precision of carbon-nitrogen budgets and assist in effective intervention measures toward vegetation recovery.

The carbon $(\mathrm{C})$ and nitrogen $(\mathrm{N})$ cycles in the terrestrial ecosystems have gained an increasing attention over the past decades because their oxides have great impacts on climate change. Soil contains the largest $\mathrm{C}$ pools with the amount of $3150 \mathrm{Pg} \mathrm{C}(1 \mathrm{Pg} \mathrm{C}=1015 \mathrm{~g} \mathrm{C})$, which is more than four times of that in plants $(650 \mathrm{Pg} \mathrm{C})$ and atmosphere (750 Pg C) (Guan et al. 2015). Of the total carbon stocks of world soils, African soils corresponded to $9 \%$ of the global SOC stock and $68 \%$ of the terrestrial C pool of Africa (Henry et al. 2009).

A large proportion of the global SOC pool is contained in forest soils and associated peat deposits. The proportion of carbon stored in soils is increased in the order of tropical, temperate, and boreal (Lal 2013) and approximately three times that of aboveground biomass (Eswaran et al. 1993). Most of this stored carbon is lost through degradation resulting in huge amounts of carbon released to the atmosphere (Eswaran et al. 1993; Lal 2004). Different studies have shown that as soil depth increase, SOC and TN accumulation decrease for all land use because of the decrease in the effects of aboveground biomass accumulation and subsequent decomposition processes especially for forest and grasslands (Yimer et al. 2006; Shrestha and Singh 2008; Sakai et al. 2010; Demessie et al. 2011; Gamfeldt et al. 2013; Habtemicael et al. 2014; Yimer et al. 2015; Mathew et al. 2016; Gurmessa et al. 2016; Liu et al. 2016). Similarly, findings (Yimer et al. 2006; Gelaw et al. 2014) have shown that the SOC did not differ significantly after a depth of $30 \mathrm{~cm}$ indicating stability between all land uses due to the low level of addition of biomass to lower depths. Studies of SOC and TN revealed that the change in $\mathrm{TN}$ follows similar patterns as that of SOC where there exists significant correlation between the two elements (Peng et al. 2013). Hence, the proper management of land and land-related resources has co-benefits to maintain the release of carbon and nitrogen to the atmosphere.

The ratio of $\mathrm{C} / \mathrm{N}$, indicators of the dynamic balance of SOC and $\mathrm{N}$ contents, reliably indicates the decomposition and mineralization rate of SOC and the cycle of $\mathrm{C}$ and $\mathrm{N}$ in ecological system to a large extent (Liu et al. 2016). With a high soil $\mathrm{C} / \mathrm{N}$ ratio, soil organic matters (SOM) decompose and mineralize very slowly and arduously. Under such circumstances, $\mathrm{N}$ would become limited in soil organic matter (SOM) resolving processes by microorganism, resulting inorganic $\mathrm{N}$ competition between plant and microorganism. This is unfavorable for the growth of plants and the accumulations of net primary productivity (NPP). In contrast, SOM with a low $\mathrm{C} / \mathrm{N}$ ratio could be decomposed and mineralized relatively easier, which facilitates the nutrients releasing of microorganism during the decomposition of SOM. As a consequence, soil available $\mathrm{N}$ would increase. The $\mathrm{C} / \mathrm{N}$ ratio is affected by land use, and hence, forested land uses are having the highest values than other land uses (Liu et al. 2016).

Maintaining SOC and TN through improvements of forest cover is an important aspect in climate change mitigation as the loss of carbon and nitrogen to the atmosphere through soil disturbances can cause an enormous addition of the elements to the atmosphere (Lemenih et al. 2005; Vágen et al. 2005; Strassburg et al. 2010; Gamfeldt et al. 2013; Berenguer et al. 2014; Gelaw et al. 2014; Gurmessa et al. 2016; Tesfaye et al. 2016). It has been found that forests and their soils store about $45 \%$ of the terrestrial carbon and act as crucial carbon sources (Gamfeldt et al. 2013; Tesfaye et al. 2016), and tropical forest ecosystem soils store about $60 \%$ of the total carbon stocks (Vágen et al. 2005). So, the maintenance of forested landscapes is one element of mitigation strategies when properly handled. But maintaining forested landscapes is becoming a challenge primarily due to competing interests of land uses for different purposes such as crop production, livestock, and settlement. In order to minimize the impacts of such competing land uses on the roles of forests in global carbon and nitrogen balance, protection and management of forest fragments within the human-modified landscapes are one of the alternative options.

Although studies (Lemenih et al. 2005; Workneh 2008; Gelaw et al. 2014; Tesfaye et al. 2016; Gurmessa et al. 2016) have clearly shown that forest ecosystems play vital roles in regulating of carbon and nitrogen losses to the atmosphere, little research has attempted to come up with the roles played by fragmented forests in improving the maintenance of SOC and $\mathrm{TN}$ in the soils 
except a study conducted by Cardelús et al. 2013and Vanderhaegen et al. (2015) in Northern and South western Ethiopia.

Due to the reduction in aboveground biomass through different impacts from human and livestock activities; there will be variation in SOC accumulation and TN across the fragments sampled with relatively higher concentration for fragments with higher diversity of species. The loss of SOC and TN is particularly significant in the context of land use changes due to the reduction in aboveground biomass (Lemenih et al. 2005; Gelaw et al. 2013; Gurmessa et al. 2016; Tesfaye et al. 2016). We also anticipate a decrease in SOC and TN as depth increases (Lemenih et al. 2005). On a general basis, SOC and TN are significantly higher under natural forest cover than other land uses depicting the important roles played by forest land uses in regulating carbon losses from soils. Many studies have been carried out to assess the impacts of changes in land uses on soil properties in general and SOC and TN in particular in Ethiopia (Lemenih et al. 2005), but few attempted to address the impacts of forest degradation and fragmentation on soil properties. Hence, this study tried to address this gap by studying different fragments at various levels of degradation and fragmentation from the continuous forests of Jibat and Chillimo. We want to test the hypothesis that soil depth and location of fragments in either Chillimo or Jibat have impacts on SOC and TN across those fragments. In addition, in this study, we want to investigate the amount of SOC and TN for each fragment sampled and see the relative soil improvement index (RSII) in relation to depth and fragment types.

\section{Study area and methods}

\section{Study area}

The study was conducted around two forest priority areas found in west Shewa zone of Dendi and Jibat district, Oromia regional state, Ethiopia (Table 1 and Fig. 1). The Chillimo-Jibat mountain chain is a mosaic of landscape that extends from the central highland further to the western part of the country. The mountain chain is characterized by fragmented forests on the escarpments, agricultural lands, and grazing lands. The forest fragments found on the mountain chain is a major source of wood products, water, and agricultural land expansion for communities in the catchment.

The main livelihood activities for the local communities living in the area include agriculture, livestock, and forest products. The majority of the communities live around the periphery of the forest fragments while few of them reside in the forest boundary. In Jibat forest, settlement is a very common phenomenon by newly migrant households from elsewhere in the country. As a result, rapid deforestation and fragmentation are evident. The two forests are regarded as a forest priority area for biodiversity conservation and timber extraction by the Oromia Forest and Wildlife Enterprise, although the forests are highly fragmented due to settlements and agricultural land expansion (Fig. 1).

The Chillimo forest is located about $80 \mathrm{~km}$ west of Addis Ababa. Its geographical location is $38^{\circ} 10^{\prime}-38^{\circ} 13^{\prime} \mathrm{E}$ and $9^{\circ} 01^{\prime}-9^{\circ} 07^{\prime} \mathrm{N}$, with altitudinal range between 2400 and 2900 m.a.s.l. (Tamrat 1993). The forest is typical dry Afromontane forest vegetation and dominated by Juniperus procera trees. Most of the forest structure is

Table 1 Fragment characteristics of Jibat and Chillimo

\begin{tabular}{|c|c|c|c|c|c|}
\hline Fragment number & Fragment name & Location & Altitude (m) & Area $\left(\mathrm{m}^{2}\right)$ & Perimeter ( $m$ ) \\
\hline 1 & Munyo Abeyi & Jibat & 2749 & $125,955.3$ & 1794.7 \\
\hline 2 & Shenen & Jibat & 2494 & $92,308.2$ & 1368.5 \\
\hline 3 & Munyo Abeyi & Jibat & 2542 & $142,141.7$ & 1788.1 \\
\hline 4 & Gara Egu & Jibat & 2735 & $32,416.6$ & 680.9 \\
\hline 5 & Abeyi Reji & Jibat & 2234 & $516,706.6$ & 4011.9 \\
\hline 6 & Abeyi Reji & Jibat & 2222 & $518,518.7$ & 3123.9 \\
\hline 7 & Abeyi Reji & Jibat & 2286 & $648,429.0$ & 4287.6 \\
\hline 8 & Abeyi Reji & Jibat & 2247 & $2,390,740.1$ & 7195.6 \\
\hline 9 & Witate & Jibat & 2468 & $80,000.1$ & 1139.9 \\
\hline 10 & Bilo & Jibat & 2171 & $40,000.1$ & 569.9 \\
\hline 11 & Gare & Chillimo & 2401 & $21,940.9$ & 460.9 \\
\hline 12 & Lega Shimela & Chillimo & 2326 & $81,250.9$ & 1706.9 \\
\hline 13 & Mesalamia & Chillimo & 2375 & $101,230.5$ & 2126.6 \\
\hline 14 & Lega Batu & Chillimo & 2298 & $33,451.2$ & 702.7 \\
\hline 15 & Kersa & Chillimo & 2266 & $20,530.2$ & 431.3 \\
\hline
\end{tabular}




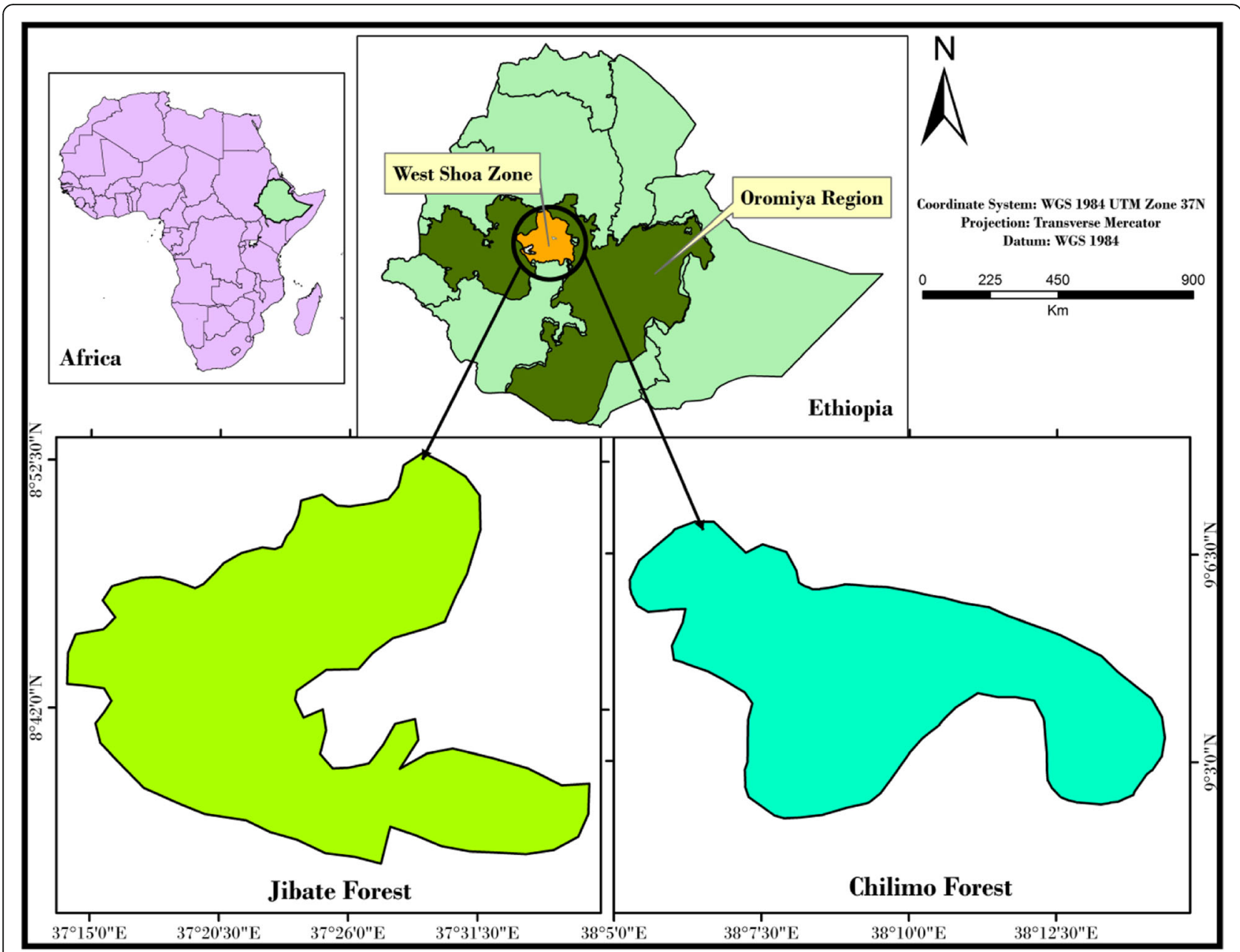

Fig. 1 Location of the study area

dominated by the largest diameter classes with low regeneration capacities due to long-term exploitation and livestock grazing (Ameha et al. 2014). Chillimo forest has been harvested for commercial timber production through selective cutting of matured trees for long period of time. The main rock type in the area is basalt, and some areas are covered with other volcanic rocks of more recent formation. The soils are reddish brown, gravelly, and shallow at higher altitudes, while at lower sites, they tend to become dark gray and deep. The soils in the surrounding low plains are vertisols, black soils with characteristic high clay content. The mean annual rainfall is $1264 \mathrm{~mm}$, with a bimodal rainfall distribution of lower precipitation from November to January, and there are five rainy months, May-September, with a peak in July. The mean annual temperature ranges between 15 and $20{ }^{\circ} \mathrm{C}$ (Tamrat 1993; Mesfin 1998).

Jibat forest is in the Jibat district of the Western Shewa administrative zone at about $194 \mathrm{~km}$ west of Addis Ababa. It is located on the mountain chains of the central highlands of Ethiopia $\left(37^{\circ} 15^{\prime}-37^{\circ} 30^{\prime} \mathrm{E} ; 8^{\circ} 35^{\prime}-\right.$ $8^{\circ} 50^{\prime} \mathrm{N}$ ) extending from the west to south portion of the lower altitudes (2000-3000 m.a.s.l.) where the forest takes a form of mosaics of landscapes with woodlands and farmlands. The forest has been heavily exploited for commercial timber production, agricultural land expansion, and logging by the communities for selling of the wood for small-scale wood industries. It is a highly disturbed forest regarded as moist Afromontane forest types (Tamrat 1993). The mean annual rainfall was $1768 \mathrm{~mm}$, and mean monthly low and high temperatures were $7.8{ }^{\circ} \mathrm{C}$ and $23.6{ }^{\circ} \mathrm{C}$, respectively, for the area between 1997 and 2006 (Tesfaye et al. 2013). The rainy season occurs from March to October with a peak in rainfall between June and September, and the dry season occurs from November to February (Tesfaye et al. 2013). The soils are reddish with highly developed horizon.

A total of 15 forest fragments were selected for SOC and TN study (five from Chillimo and 10 from Jibat). The forest fragments selected for analysis of SOC and 
$\mathrm{TN}$ in this case were separated through fragmentation over time and are surrounded by cultivated land/grazing land, but they were once part of these forests. In this forest fragments, harvesting of forest products and cattle grazing are regular phenomenon (personal observation). In each fragment, two to five $20 \mathrm{~m} \times 20 \mathrm{~m}$ plots were placed depending on the area of the fragment to take soil samples at two depths. In each plot, we opened a pit (one at the center and four at the corner of our quadrant) with a $10 \mathrm{~cm} \times 10 \mathrm{~cm}$ and took soil sample for two depths $(0-30 \mathrm{~cm}$ and $30-60 \mathrm{~cm})$.

\section{Soil sample collection and analysis}

We collected soil samples from two soil depths: 0$30 \mathrm{~cm}$ and $30-60 \mathrm{~cm}$. The two soil depths were selected to investigate the difference between the soil depths because it is generally accepted by many studies that there is a difference between the soil depths. Soil samples from 15 fragments with two soil depth classes were collected for the analysis: A sample of soil from each depth was collected, crushed, air-dried at room temperature, passed through a 2-mm sieve, homogenized to obtain a composite soil, and sent to laboratory for analysis. Soil bulk density $\left(\rho_{b}\right)$ samples were taken for the same depth intervals as other soil samples for each plot by the core sampler height $10 \mathrm{~cm}$ and diameter $7.2 \mathrm{~cm}$ smoothly pushed against the northern faces of the pits. Bulk density is critical for converting organic carbon percentage by weight to content by volume (Batjes 1996). In general, bulk density was determined by the core sampling method.

The soil organic carbon determinations were made following the wet oxidation method of Walkley and Black 1934 and Batjes 1996, and TN concentration was determined with the Kjeldahl procedure (Jackson 1958; Batjes 1996) at the Ambo University soil laboratory. The SOC density $\left(\mathrm{SOC}_{\mathrm{d}}, \mathrm{Mg} / \mathrm{ha}\right)$ and $\mathrm{TN}$ density $\left(\mathrm{TN}_{\mathrm{d}}, \mathrm{Mg} / \mathrm{ha}\right)$ of the two soil layers in each quadrat were calculated by the following equation using the fixed-depth method. Although this method is criticized as it does not account for the influence of soil mass on estimates of organic matter and nutrient storage, it is still widely used (Ellert and Bettany 1995).

$$
\begin{aligned}
& \mathrm{SOC}_{\mathrm{d}}=\mathrm{SOC}_{i} \times \rho_{i} \times H_{i} / 10 \\
& \mathrm{TN}_{\mathrm{d}}=\mathrm{STN}_{i} \times \rho_{i} \times H_{i} / 10
\end{aligned}
$$

where $\mathrm{SOC}_{\mathrm{i}}, \mathrm{STN}_{\mathrm{i}}, \rho_{\mathrm{i}}$, and $H_{\mathrm{i}}$ represent soil organic carbon concentration $(\mathrm{g} / \mathrm{kg})$, soil total nitrogen concentration $(\mathrm{g} /$ $\mathrm{kg}$ ), soil bulk density $\left(\mathrm{g} / \mathrm{cm}^{3}\right)$, and soil thickness $(\mathrm{cm})$ in the layer i, respectively. Cumulative soil organic $\mathrm{C}$ and soil total $\mathrm{N}$ stocks to $0.60 \mathrm{~m}$ mineral soil were calculated by adding the soil $\mathrm{C}$ or total $\mathrm{N}$ stocks of the $0-30$ and $30-60 \mathrm{~cm}$ soil increments. $\mathrm{C} / \mathrm{N}$ ratio was also calculated on the basis of $\mathrm{SOC} / \mathrm{TN}$ to see the rate of mineralization processes.

Furthermore, the SOC and TN for fragments were averaged to the two study sites and presented.

In addition, variation in soil properties across fragments and soil depths were computed by taking fragment fourteen $\left(F_{14}\right)$ and $0-30 \mathrm{~cm}$ soil depth as reference groups, respectively. Hence, for a given soil property, the variation expresses how much it increased or decreased in percent in relation to the reference group (Table 1). For example, variation (\%) for fragment one $\left(\mathrm{F}_{1}\right)$ and for $30-60 \mathrm{~cm}$ soil depth for a given soil property was computed as:

$$
\begin{aligned}
& \text { Variation }_{\mathrm{F} 1}(\%)=\left(\frac{\text { Value }_{\mathrm{F} 1}-\text { Value }_{\mathrm{F} 14}}{\text { Value }_{\mathrm{F} 14}}\right) \times 100 \\
& \text { Variation }_{30-60}(\%)=\left(\frac{\text { Value }_{30-60}-\text { Value }_{0-30}}{\text { Value }_{0-30}}\right) \times 100
\end{aligned}
$$

To assess the relative soil improvement effect of the land uses, a Relative Soil Improvement Index (RSII) was used. Unlike the soil deterioration index, which assumes the adjacent natural forest or woodland or savannah as a reference land use, in RSII rather, the comparison is made against the more prevalent fragment type (Islam and Weil 2000; Duguma et al. 2010). Thus, the applicability of RSII is more imperative in cases where there are severe disturbances of the landscape structures because of human and livestock overpopulation, which challenge the existence of the adjacent "ideal" land use type to which we compare the others.

In this study, RSII was computed only based on SOC, $\mathrm{TN}, \mathrm{C} / \mathrm{N}, \mathrm{pH}$, and $\mathrm{BD}$. The fragments (fourteen fragments $\left(\mathrm{F}_{14}\right)$ in our case) were compared against one fragment (fragment fourteen $\left(\mathrm{F}_{14}\right)$ ) to see how better the soils under different fragments are as compared to the reference one (fragment fourteen $\left(\mathrm{F}_{14}\right)$. Fragment fourteen $\left(\mathrm{F}_{14}\right)$ is the very dominant land use type in central highlands of Ethiopia as deforestation and degradation are pervasive. Then, the variation (\%) of the five soil properties computed using the above equation is summed together to get the RSII value of a given land use type.

$$
\operatorname{RSII}_{\text {fragment }}(\%)=\sum \text { Variation }_{\text {fragment }}(\mathrm{SOC}, \mathrm{TN}, \mathrm{C} / \mathrm{N}, \mathrm{pH}, \mathrm{BD})
$$

Finally, after the total amount of SOC and TN was determined for the fragments, the values were averaged for Chillimo and Jibat study sites. 


\section{Results and discussions}

\section{SOC and TN stocks for different fragments}

Our results have shown variation among soil depth and fragments for SOC and TN (Figs. 2 and 3). On a general basis, we have found that there exists a clear decrease in SOC and TN as depth increase, in addition when the overall SOC and TN is considered for the two locations, that is, Chillimo and Jibat have shown a similar trend. SOC and TN value was the highest for fragment four ( $\mathrm{SOC}=42.15 \mathrm{Mg} / \mathrm{ha}, \mathrm{TN}=4.23 \mathrm{Mg} / \mathrm{ha}$ ) and the least value for fragment fourteen $(\mathrm{SOC}=1.86 \mathrm{Mg} / \mathrm{ha}, \mathrm{TN}=$ $0.24 \mathrm{Mg} / \mathrm{ha}$ ). SOC values for Chillimo and Jibat are comparable with the results reported for Gedo forests (Yohannes et al. 2015; Birhane et al. 2017). The result obtained from Chillimo forest fragments is comparatively similar to what has been reported (Demessie et al. 2013; Tesfaye et al. 2016; Han et al. 2018).

On a general basis, the moist Afromontane forests of Jibat forest fragments $(\mathrm{SOC}=29.88 \mathrm{Mg} / \mathrm{ha}, \mathrm{TN}=$ $2.84 \mathrm{Mg} / \mathrm{ha}$ ) accumulated larger amounts of SOC and TN as compared to the dry Afromontane forests of Chillimo $(\mathrm{SOC}=14.06 \mathrm{Mg} / \mathrm{ha}, \mathrm{TN}=1.40 \mathrm{Mg} / \mathrm{ha})$. For the two parameters measured, the values are twice larger for Jibat forest fragments than Chillimo forest fragments indicating the importance of the first for carbon accumulation although Chillimo is also very important in carbon accumulation potentials (Fig. 3). The difference in SOC and TN accumulation between Jibat and Chillimo could be attributed to the type of vegetation, soil type, human disturbances through removal of vegetation, excessive cattle grazing, parent material, and other climatic factors (Lal 2004; Lal 2005; Lemenih and Itanna 2004; Shrestha and Singh 2008; Demessie et al. 2011; Fang et al. 2012; Gurmesa et al. 2013; Gurmessa et al. 2016; Tesfaye et al. 2016; Berihu et al. 2017; Amanuel et al. 2018).

The SOC for the fragments ranged from 1.86 to $42.15 \mathrm{Mg} / \mathrm{ha}$, and the TN concentration ranged from 0.24 to $4.23 \mathrm{Mg} / \mathrm{ha}$. For both study sites, that is, for Jibat, $50.95 \%$ of the SOC and $63.7 \%$ of TN are held within $0-30 \mathrm{~cm}$ soil layer, whereas for Chillimo, $67.4 \%$ of the SOC and $67.9 \%$ of TN are held within $0-30 \mathrm{~cm}$ soil layer (Figs. 2 and 3). The values of SOC and TN found in these fragments are within the range of results obtained elsewhere in Ethiopia (Lemenih et al. 2005; Demessie et al. 2011; Demessie et al. 2013; Berihu et al. 2017; Amanuel et al. 2018). The relatively modest amount of SOC and TN could be very important for regulating climate change and improving the ecosystem services of soils in particular and the fragments in general (Bavey et al. 2016) and for improving restoration of vegetation for more carbon and nitrogen sequestration to climate change mitigation (Lal 2004). Despite the higher disturbances in the forests sampled through cutting and cattle grazing (personal observation), the SOC and TN are found to be higher due the low level of disturbance on the soil through erosion and tillage practices. The soil surfaces are protected against erosion by low level of cover but still provided sub-optimal conditions for maintaining soil structure.

We found huge variations among fragments in terms of the total amounts of carbon and nitrogen at the two depths sampled. Despite the importance of these forest fragments for carbon accumulation in the soils, the conservation efforts made so far to reduce the pressure are

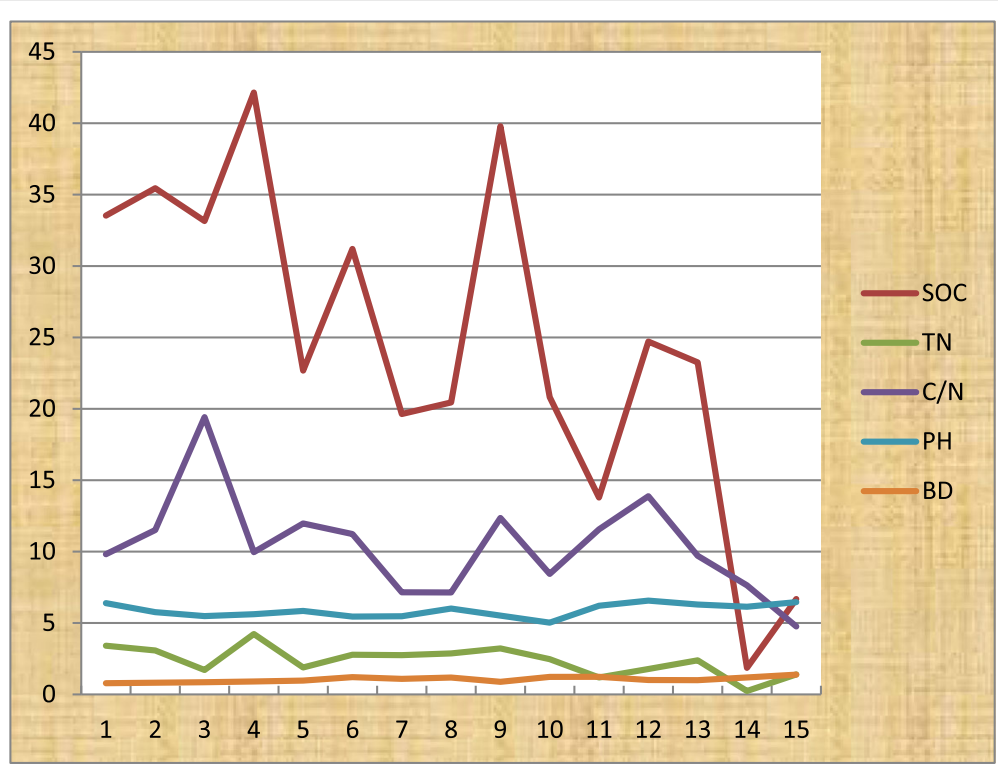

Fig. 2 Some soil chemical and physical properties for each fragment $(0-60 \mathrm{~cm})$ 


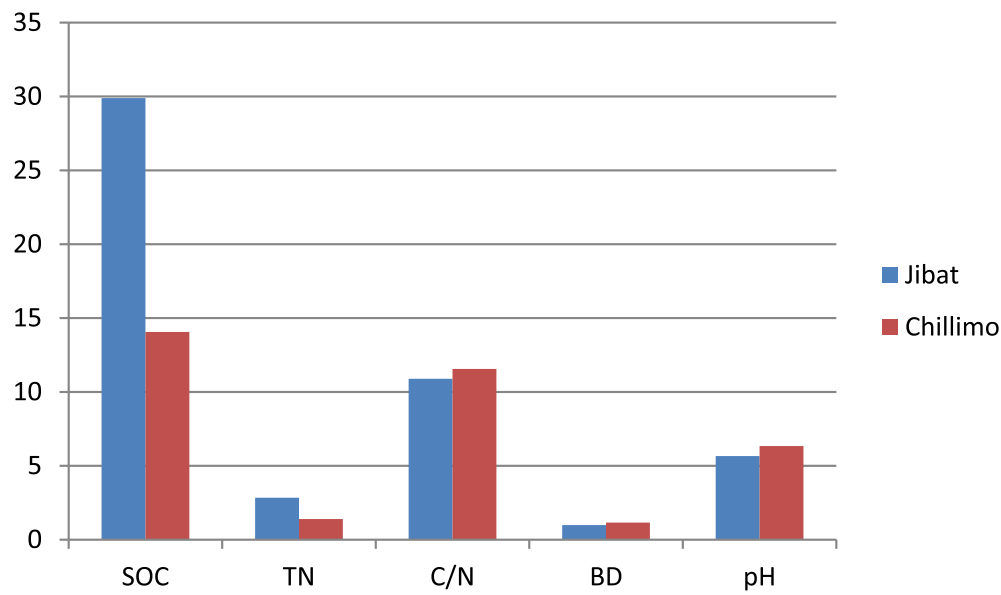

Fig. 3 SOC, TN, C/N, BD, and PH for Jibat and Chillimo forest fragment soils $(0-60 \mathrm{~cm})$

very minimal and hence this finding calls for concerted efforts to be made to reduce the pressure through payment for environmental services of the fragments in such highly modified landscapes of the central highlands of Ethiopia.

Soils with different vegetation have different litter decomposition processes leading to the difference in release of carbon and nitrogen to soil. Tree species with different plant characteristics and stands can impact retention and sequestration of soil organic carbon and nitrogen. This may be partly explained by the increase in aboveground biomass and litter that add more organic matter to the soil. As the top soil layer is susceptible to different soil management practices in terms of carbon and nitrogen losses, it is important to manage those disturbed forest fragments for optimal sequestration of carbon. The results displayed that depth and bulk density are an important factor in $\mathrm{C}$ and $\mathrm{N}$ concentrations for assessment of SOC and TN (Tables 2 and 3). The variation in soil properties particularly SOC and TN could be related to the levels of disturbances, and such level of disturbances is very difficult to estimate as each fragments separated from the continuous forest of Jibat and Chillimo took place at different period of time with various levels of interferences. What we surely know from our observation during data collection and LU/LC

Table 2 Variation (\%) in soil properties between 30-60 cm and 0-30 cm soil depth compared to values of 0-30 cm soil depth in Jibat and Chillimo forest fragments (RSII)

\begin{tabular}{lll}
\hline Soil properties & Jibat & Chillimo \\
\hline SOC & 0.18 & 3.44 \\
TN & 5.62 & 19.39 \\
C/N & -63.54 & -6.32 \\
BD & -2.78 & 48.12 \\
pH & 1.01 & -2.04 \\
\hline
\end{tabular}

analysis is that these forest fragments were slowly separated from the continuous forests within four to five decades (Tolessa et al. 2016; Tolessa et al. 2017) and the open access nature for cattle grazing, firewood collection, and timber extraction made these fragments poorly stocked. So, forest degradation affected SOC and TN within the soils although we found difference between fragments in terms of their soil properties.

\section{Carbon/nitrogen ratio ( $\mathrm{C} / \mathrm{N}$ ratio)}

The $\mathrm{C} / \mathrm{N}$ ratio is a good indicator of the degree of decomposition and quality of the organic matter held in the soil. Similar to SOC and TN values, we found variation between the fragments in relation to $\mathrm{C} / \mathrm{N}$ ratio (Figs. 2 and 3). Our results on $\mathrm{C} / \mathrm{N}$ ratio for the fragments are comparable with the findings (Gurmessa et al.

Table 3 Variation (\%) in soil properties between fragments taking fragment fourteen $\left(\mathrm{F}_{14}\right)$ as a reference (RSII)

\begin{tabular}{lllllll}
\hline Fragment & SOC & TN & C/N & $\mathrm{pH}$ & $\mathrm{BD}$ & $\mathrm{Sum}$ \\
\hline 1 & 1702.69 & 1320.8 & 28.53 & 4.15 & -33.76 & 3022.41 \\
2 & 1805.9 & 1183.3 & 50.65 & -6.19 & -33.76 & 3006.1 \\
3 & 1682.3 & 612.5 & 154.19 & -10.67 & -27.85 & 1240.97 \\
4 & 2166.13 & 1662.5 & 30.37 & -8.55 & -23.63 & 3826.82 \\
5 & 1119.35 & 687.5 & 56.68 & -4.72 & -18.14 & 1840.67 \\
6 & 1577.42 & 1058.3 & 46.99 & -11.24 & -2.11 & 2669.36 \\
7 & 955.91 & 1045.83 & -6.41 & -10.83 & -8.02 & 1976.48 \\
8 & 999.46 & 1095.83 & -6.54 & -2.04 & -0.42 & 2086.29 \\
9 & 2039.25 & 1241.67 & 61.78 & -10.01 & -25.32 & 3307.37 \\
10 & 1019.35 & 929.17 & 10.47 & -18.16 & 3.79 & 1944.62 \\
11 & 641.39 & 395.83 & 51.31 & 1.14 & 4.23 & 1039.9 \\
12 & 1228.49 & 641.67 & 81.68 & 7.00 & -14.77 & 1944.07 \\
13 & 1150 & 895.83 & 27.09 & 2.52 & -16.03 & 2059.41 \\
15 & 259.14 & 483.33 & -37.69 & 5.21 & 16.88 & 726.87 \\
\hline
\end{tabular}


2016). The highest $\mathrm{C} / \mathrm{N}$ ratio was recorded for fragment three $(\mathrm{C} / \mathrm{N}=19.42)$ and the lowest for fragment fifteen $(\mathrm{C} / \mathrm{N}=4.76)$. When we take soil depth as a factor for determining $\mathrm{C} / \mathrm{N}$ ratio, the results have shown that $\mathrm{C} / \mathrm{N}$ ratio decreased for fragments.

The highest $\mathrm{C} / \mathrm{N}$ ratio was recorded for fragment three $\left(\mathrm{F}_{3}\right)$ with a depth of $0-30 \mathrm{~cm}(\mathrm{C} / \mathrm{N}=35.36)$, while the lowest value was obtained for fragment fifteen $(\mathrm{C} / \mathrm{N}=$ 3.71). The higher values of $\mathrm{C} / \mathrm{N}$ ratio for fragment three $\left(\mathrm{F}_{3}\right)$ can be related to the low level of mineralization processes and inherent soil condition. Our result for $\mathrm{C} / \mathrm{N}$ ratio is comparatively within the range of global $\mathrm{C} / \mathrm{N}$ ratio (Batjes 1996). Comparing $\mathrm{C} / \mathrm{N}$ ratio between Jibat and Chillimo, we found that Jibat forest fragments $(\mathrm{C} / \mathrm{N}$ $=10.89$ ) had the lowest $\mathrm{C} / \mathrm{N}$ ratio than Chillimo forest fragments $(\mathrm{C} / \mathrm{N}=11.56)$ (Fig. 3). The relatively higher value of $\mathrm{C} / \mathrm{N}$ ratio for Chillimo forest fragment can be an indication of the rate of decomposition processes which can be related to moisture conditions of the location rather than the amount of organic matter addition to the soil, that is, in relative terms, precipitation amounts for Jibat are much better than for Chillimo as climatic factors and the presence of optimal amounts of $\mathrm{TN}$ are required for decomposition processes (Gurmessa et al. 2016).

The mean $\mathrm{C} / \mathrm{N}$ ratio for the $0-30 \mathrm{~cm}$ and $30-60 \mathrm{~cm}$ depth interval is not very much different for Chillimo where vertisols are dominant within the fragments sampled; this reflects the intense mixing or churning typical of these deep cracking and swelling clay soils. Further, the quality of biomass added to the soil is also very important to be considered as the rate of mineralization depends on the material added to the soil (Shrestha and Singh 2008; Gurmessa et al. 2016; Tesfaye et al. 2016; Berihu et al. 2017).

\section{Soil pH}

The soils in Chillimo forest fragments are found to be near neutral $\mathrm{pH}$ condition (6.34) than Jibat (5.66) possibly due to the characteristics of the vegetation, nature of the parent material, and precipitation. As depth increased, soil $\mathrm{pH}$ increased for both locations although the increase is not significantly higher (Figs. 2 and 3). The near neutral nature of Chillimo forest fragment soil is similar to other findings (Workneh 2008; Duguma et al. 2010), whereas other findings such as Raymond and Ronald (2003) indicated that forest soils are often more acidic similar to Jibat forest fragment soils. This is because plants release $\mathrm{H}^{+}$in exchange for cation during growth, which amounts to large amounts transferred to the soil because of the massive biomass accumulation in forests and because tree litter commonly is acidic and releases hydrogen ion up on decomposition. They further discussed that tree may naturally acidify the soil by taking up and storing in woody tissues calcium, magnesium, and other elements that tend to form bases in the soil. Soil pH influences the availability of some nutrients, both through direct geochemical effects and through indirect effects on microbial activity. This can be substantiated by the findings of Demessie et al. (2011) where soil $\mathrm{pH}$ values can be affected by the quality of litter falling from plants.

\section{Soil bulk density}

As expected, soil bulk density is related to the amount of organic matter present in the soil. Hence, it affects SOC and TN within the soil layers. Soil bulk density (BD) also varied between fragments. The lowest soil BD was recorded for fragment one $\left(\mathrm{F}_{1}\right)$ with the value of $0.785 \mathrm{~g} / \mathrm{cm}^{3}$ while the highest was recorded for fragment fifteen $\left(\mathrm{F}_{15}\right)$ with a value of $1.385 \mathrm{~g} / \mathrm{cm}^{3}$ (Figs. 2 and 3). The increase in bulk density as depth increase can be the result of lower level of accumulation of organic matter in the lower soil horizons as compared to upper where regular falling of biomass occurs frequently when parts of the plant die off due to various reasons.

Bulk density was significantly influenced by type of land use and soil depth. Higher bulk densities were observed in degraded land and subsoil, due to higher soil compaction, higher erosion rate, lack of inputs, and low soil fertility which is similar to other findings (Tesfaye et al. 2016). This is evident in Chillimo forest fragments where the bulk density is higher as compared to Jibat forest fragments. The increase in soil $\mathrm{BD}$ as depth increase for all fragments is similar to other findings elsewhere (Demessie et al. 2011; Fang et al. 2012). The values of $\mathrm{BD}$ obtained for our study site is within the range set on the global level (Batjes 1996).

\section{Relative Soil Improvement Index}

When $30-60 \mathrm{~cm}$ soil depth is considered taking $0-$ $30 \mathrm{~cm}$ as baseline over the two study locations, Jibat had lower RSII values in SOC, TN, C/N ratio, and $\mathrm{BD}$ which showed Chillimo forest had higher values in $\mathrm{TN}$ and $\mathrm{BD}$ (Table 3) indicating soils in Chillimo are inherently different in their development due to the impacts of soil forming factors (Duguma et al. 2010).

Fragment four $\left(\mathrm{F}_{4}\right)$ had a RSII value of $3826.82 \%$ followed by fragment nine $\left(\mathrm{F}_{9}\right)(3307.37 \%)$ and lastly fragment fifteen $\left(\mathrm{F}_{15}\right)(726.87 \%)$ (Table 3). These values indicate that fragment four $\left(\mathrm{F}_{4}\right)$ soils are very good relative to fragment fourteen $\left(\mathrm{F}_{14}\right)$ soils in $\mathrm{SOC}, \mathrm{TN}, \mathrm{C} / \mathrm{N}$, $\mathrm{BD}$, and $\mathrm{pH}$ in the study area. It is not so surprising if fragment fourteen $\left(\mathrm{F}_{14}\right)$ had the lowest values in soil properties because it has the lowest vegetation cover with rock out crops dominating the area with little addition of biomass to the soil (personal observation). This fragment is under continuous grazing, removal of 
trees/shrubs for firewood, and construction materials and is open access for a variety of disturbances which results in low level of soil properties given its natural soil properties added (Tables 1 and 3). This finding is in agreement with the study conducted by Duguma et al. (2010) where cereal land use has the lowest RSII in which this particular land use is highly disturbed through cultivation and land under cultivation (Islam and Weil 2000).

When all the soil properties are taken into account (Tables 2 and 3), fragment four $\left(F_{4}\right)$ is with better soil quality parameters while fragment fourteen $\left(\mathrm{F}_{14}\right)$ is the least. Others lie in between the two fragments considered; hence, the variability of these properties calls for management of each fragment in accordance with their status for restoration and recovery of ecosystem services provided by the fragments as a whole. This finding is in line with the results obtained elsewhere in Ethiopia where homestead as an alternative agroforestry land use is with diverse vegetation and higher accumulation of litter as compared cereal land use (Duguma et al. 2010).

\section{Conclusion}

Our results have shown higher amounts of SOC and TN in Jibat forest $(29.89 \mathrm{Mg} / \mathrm{ha}$ and $2.84 \mathrm{Mg} / \mathrm{ha}$ ) than in Chillimo $(14.06 \mathrm{Mg} / \mathrm{ha}$ and $1.40 \mathrm{Mg} / \mathrm{ha})$ for $0-60 \mathrm{~cm}$ depth. We found that forest degradation and fragmentation are important factors in altering the dynamics of soil properties and hence considering them an integral part of land management practices is vital for resource managers. Each forest fragment has shown variations in SOC, TN, C/N, $\mathrm{pH}$, and $\mathrm{BD}$ at different soil depths considered. RSII values for each fragment showed better quality soil properties for F4 as compared to F14, but the values are mixed for the two study areas when soil depth is referenced.

Given the low level of stand density and canopy cover, the aboveground carbon stock is comparably higher which clearly shows that forest fragments left as patches in the middle of human-modified landscapes are very important repositories of SOC and $\mathrm{TN}$ which otherwise may be released to the atmosphere through land degradation. Forest fragments have a potential avenue for climate change mitigation if properly managed. In order to improve the provision of the environmental services of forest fragments, maintaining the aboveground vegetation and enhancing its restoration is very vital. The restoration processes should take in to account the potential roles of these fragments alongside with its biodiversity conservation where these patches could serve as stepping stones for future rehabilitation of the degraded landscapes of the central highlands of Ethiopia. To this end, payment for the environmental services can also be an opportunity to be explored to enhance its sustainability and future restoration programs.

\section{Acknowledgement}

The authors acknowledge the financial support received from Ambo University for soil sample collection from the forest fragments and soil analysis. We also would like to thank the anonymous reviewers and editors for their constructive comments on the write-up of the paper.

\section{Funding}

This research was funded by Ambo University.

\section{Availability of data and materials}

Landsat images were downloaded from US Geological Survey (USGS) Center for Earth Resources Observation and Science (EROS), and GIS was used to generate the study area.

\section{Authors' contributions}

Both authors equally participated in generating the research idea, designing the methods, analyzing the data, and writing the manuscript. Both authors read and approved the final manuscript.

\section{Authors' information}

Terefe Tolessa holds PhD in Development Studies (Environment and Development) at Ambo University and lecturer and researcher at the Department of Disaster Risk management. He is offering courses on sustainable development and advising 10 MSc students in diverse range of development, environment and other issues. He has published five articles on different journals. His areas of interest include ecosystem service, land use/land cover dynamics, fragmentation, forest environmental income, and climate change sciences.

Feyera Senbeta Wakjira holds PhD degree in Forest Ecology, and he is a lecturer and researcher at Addis Ababa University. His area of interest includes ecosystem services, vegetation ecology, landscape ecology, and environmental sciences.

\section{Ethics approval and consent to participate}

Not applicable to this manuscript submission.

\section{Consent for publication}

The manuscript does not contain any data or information from any person or individual apart from own field investigation. All data and information are generated and synthesized by the authors.

\section{Competing interests}

The authors declare that they have no competing interests.

\section{Publisher's Note}

Springer Nature remains neutral with regard to jurisdictional claims in published maps and institutional affiliations.

\section{Author details}

${ }^{1}$ Institute of Cooperatives and Development Studies, Ambo University, Ambo, Ethiopia. ${ }^{2}$ College of Development Studies, Addis Ababa University, Addis Ababa, Ethiopia.

Received: 9 August 2018 Accepted: 18 October 2018

Published online: 03 November 2018

\section{References}

Amanuel W, Yimer F, Karltun E. Soil organic carbon variation in relation to land use changes: the case of Birr watershed, upper Blue Nile River Basin, Ethiopia. J Ecol Environ. 2018:42:16.

Ameha A, Larson HO, Lemenih M. Participatory forest management in Ethiopia: learning from pilot projects. Environ Manag. 2014;53:838-54.

Batjes NH. Total carbon and nitrogen in the soils of the world. Eur J Soil Sci. 1996;47:151-63.

Bavey PC, Baveye J, Gowdy J. Soil "ecosystem" services and natural capital: critical appraisal of research on uncertain ground. Front Environ Sci. 2016. https:// doi.org/10.3389/fenvs.2016.00021.

Beniston JW, DuPont ST, Glover JD, Lal R, Dungait JAJ. Soil organic carbon dynamics 75 years after land-use change in perennial grassland and annual wheat agricultural systems. Biogeochemistry. 2014. https://doi.org/10.1007/ s10533-014-9980-3. 
Bennett AF, Saunders DA. Habitat fragmentation and landscape change. In: Sodhi NS, Ehrlich PR, editors. Conservation biology for all: Oxford University Press. doi; 2010. https://doi.org/10.1093/acprof:oso/9780199554232.001.0001.

Berenguer E, Ferreira J, Gardner TA, Aragao LEOC, de Camargo PB, Cerri CE, Durigan M, de Oliveira RC, Vieira IG, Barlow J. A large-scale field assessment of carbon stocks in human-modified tropical forests. Glob Chang Biol. 2014; 20:3713-26.

Berihu T, Girmay G, Sebhatleab M, Berhane E, Zenebe A, Sigua G. Soil carbon and nitrogen losses following deforestation in Ethiopia. Agron Sustain Dev. 2017; 37:1. https://doi.org/10.1007/s13593-016-0408-4.

Birhane E, Treydte AC, Eshete A, Solomon N, Hailemariam M. Can rangelands gain from bush encroachment? Carbon stocks of communal grazing lands invaded by Prosopis juliflora. J Arid Environ. 2017;141:60-7.

Cardelús CL, Scull P, Hair J, Baimas-George M, Lowman MD, Wassie AE. A preliminary assessment of Ethiopian sacred grove status at the landscape and ecosystem scales. Diversity. 2013;5:320-34.

Chen D, Mi J, Chu P, Cheng J, Zhang L, Pan Q, Xie Y, Bai Y. Patterns and drivers of soil microbial communities along a precipitation gradient on the Mongolian Plateau. Landsc Ecol. 2015;30:1669-82.

Demessie A, Signh BR, Lal R. Soil carbon and nitrogen stocks under plantations in Gambo District, Southern Ethiopia. J Sustain For. 2011;30:496-517.

Demessie A, Singh BR, Lal R. Soil carbon and nitrogen stocks under chronosequence of farm and traditional agroforestry land uses in Gambo District, Southern Ethiopia. Nutr Cycl Agroecosyst. 2013;95:365-75.

Dingpeng X, Peili S, Yinliang S, Jianshuang W, Xianzhou Z. Effects of grazing exclusion on plant productivity and soil carbon, nitrogen storage in alpine meadows in northern Tibet, China. Chin Geogra Sci. 2014;24(4):488-98.

Duguma LA, Hager H, Sieghardt M. Effects of land use types on soil chemical properties in smallholder farmers of central highland Ethiopia. Ekologia (Bratislava). 2010;29(1):1-14.

Echeverria C, Coomes D, Salas J, Rey-Benayas JM, Lara A, Newton A. Rapid deforestation and fragmentation of Chilean temperate forests. Biol Conserv. 2006;130:481-94.

Ellert BH, Bettany JR. Calculation of organic matter and nutrients stored in soils under contrasting management regimes. Can J Soil Sci. 1995;75:529-38.

Eswaran H, Van Den Berg E, Reich P. Organic carbon in soils of the world. Soil Sci Soc Am J. 1993;57:192-4.

Fang X, Xue Z, Li B, An S. Soil organic carbon distribution in relation to land use and its storage in a small watershed of the Loess Plateau, China. Catena. 2012;88:6-13.

Gamfeldt L, Snäll T, Bagchi R, Jonsson M, Gustafsson L, Kjellander P, Ruiz-Jaen MC, Fröberg M, Stendah J, Philipson CD, Mikusiński G, Andersson E, Westerlund B, Andrén H, Moberg F, Moen J, Bengtsson J. Higher levels of multiple ecosystem services are found in forests with more tree species. Nat Commun. 2013:4:1340. https://doi.org/10.1038/ncomms2328, www.nature $\mathrm{com} /$ naturecommunications.

Gelaw AM, Singh BR, Lal R. Organic carbon and nitrogen associated with soil aggregates and particle sizes under different land uses in Tigray, Northern Ethiopia. Land Degrad Develop. https://doi.org/10.1002/ldr.2261.

Gelaw AM, Singh BR, Lal R. Soil organic carbon and total nitrogen stocks under different land uses in a semi-arid watershed in Tigray, Northern Ethiopia. Agric Ecosyst Environ. 2014;188:256-63.

Guan F, Tang X, Fan S, Zhao J, Peng C. Changes in soil carbon and nitrogen stocks followed the conversion from secondary forest to Chinese fir and Moso bamboo plantations. Catena. 2015. https://doi.org/10.1016/j.catena. 2015.03.002.

Gurmesa GA, Schmidt IK, Gundersen P, Vesterdal L. Soil carbon accumulation and nitrogen retention traits of four tree species grown in common gardens. For Ecol Manag. 2013;309:47-57.

Gurmessa B, Demessie A, Lemma B. Dynamics of soil carbon stock, total nitrogen, and associated soil properties since the conversion of Acacia woodland to managed pastureland, parkland agroforestry, and treeless cropland in the Jido Komolcha District, southern Ethiopia. J Sustain For. 2016;35(5):324-37.

Habtemicael M, Yayneshet T, Treydte AC. Responses of vegetation and soils to three grazing management regimes in a semi-arid highland mixed croplivestock system. Afr J Ecol. 2014;53:75-82.

Han Y-S, Lee E-P, Park J-H, Lee S-I, Lee S-Y, You Y-H. Organic carbon distribution and cycling in the Quercus glauca forest at Gotjawal wetland, Jeju Island, Korea. J Ecol Environ. 2018:42:8.

Henry M, Valentini R, Bernoux M. Soil carbon stocks in ecoregions of Africa. Biogeosci Discuss. 2009;6:797-823.
Islam KR, Weil RR. Land use effects on soil quality in a tropical forest ecosystem of Bangladesh. Agric Ecosyst Environ. 2000;79:9-16.

Jackson ML. Soil chemical analysis. New Jersey: Prentice Hall, Inc; 1958. p. 183-204.

Jiménez JJ, Lal R, Leblan HA, Russo RO. Soil organic carbon pool under native tree plantations in the Caribbean lowlands of Costa Rica. For Ecol Manag. 2007;241:134-44.

Lal R. Soil carbon sequestration to mitigate climate change. Geoderma. 2004;123: $1-22$.

Lal R. Forest soils and carbon sequestration. For Ecol Manag. 2005;220:242-58.

Lal R. Soil carbon management and climate change. Carbon Manage. 2013;4(4): 439-62.

Lemenih M, Itanna F. Soil carbon stocks and turnovers in various vegetation types and arable lands along an elevation gradient in southern Ethiopia. Geoderma. 2004;123:177-88.

Lemenih M, Lemma B, Teketay D. Changes in soil carbon and total nitrogen following reforestation of previously cultivated land in the highlands of Ethiopia. SINET: Ethiop J Sci. 2005;28(2):99-108.

Liu M, Ussiri DAN, Lal R. Soil organic carbon and nitrogen fractions under different land uses and tillage practices. Commun Soil Sci Plant Anal. 2016; 47(12):1528-41.

Mathew MM, Majule AE, Sinclair F, Marchant R. Relationships between on-farm tree stocks and soil organic carbon along an altitudinal gradient, Mount Kilimanjaro, Tanzania. For Trees Livelihoods. 2016;25(4):255-66.

Mesfin A. Nature and management of Ethiopian soils. Ethiopia: Alemaya University of Agriculture; 1998. p. 272.

Moraes JL, Cerri CC, Melillo JM, Kicklighter D, Neill C, Skole DL, Steudler PA. Soil carbon stocks of the Brazilian Amazon basin. Soil Sci Soc Am J. 1995;59:244-7.

Navarrete IA, Tsutsuki K. Land-use impact on soil carbon, nitrogen, neutral sugar composition and related chemical properties in a degraded Ultisol in Leyte, Philippines. Soil Sci Plant Nutr. 2008;54:321-31.

Peng G, Bing W, Guangpo G, Guangcan Z. Spatial distribution of soil organic carbon and total nitrogen based on GIS and geostatistics in a small watershed in a hilly area of northern China. PLoS One. 2013;8(12):e83592. https://doi.org/10.1371/journal.pone.0083592.

Raymond YA, Ronald LG. Introduction to forest ecosystem science and management. 3rd ed. Hoboken: Wiley; 2003. p. 576.

Sakai H, Inagaki M, Noguchi K, Sakata T, Yatskov MA, Tanouchi H, Takahashi M. Changes in soil organic carbon and nitrogen in an area of Andisol following afforestation with Japanese cedar and Hinoki cypress. Soil Sci Plant Nutr. 2010;56:332-43.

Shrestha BM, Singh BR. Soil and vegetation carbon pools in a mountainous watershed of Nepal. Nutr Cycl Agroecosyst. 2008;81:179-91.

Strassburg BBN, Kelly A, Balmford A, Davies RG, Gibbs HK, Lovett A, Miles L, Orme CDL, Price J, Turner RK, Rodrigues ASL. Global congruence of carbon storage and biodiversity in terrestrial ecosystems. Conserv Lett. 2010;3:98-105.

Tamrat B. Vegetation ecology of remnant Afromontane forests on the central plateau of Shewa, Ethiopia. Acta Phytogeographica Suecica. 1993;79:1-64

Tesfaye D, Fashing PJ, Bekele A, Mekonnen A, Atickem A. Ecological flexibility in Boutourlini's Blue Monkeys (Cercopithecus mitis boutourlinii) in Jibat forest, Ethiopia: a comparison of habitat use, ranging behavior, and diet in intact and fragmented forest. Int J Primatol. 2013;34:615-40.

Tesfaye MA, Bravo F, Ruiz-Peninado R, Pando V, Bravo-Oviedo A. Impact of changes in land use, species and elevation on soil organic carbon and total nitrogen in Ethiopian Central Highlands. Geoderma. 2016;261:70-9.

Tolessa T, Senbeta F, Kidane M. Landscape composition and configuration in the central highlands of Ethiopia. Ecol Evol. 2016;6:7409-21.

Tolessa T, Senbeta F, Kidane M. The impact of land use/land cover change on ecosystem services in the central highlands of Ethiopia. Ecosyst Serv. 2017;23: 47-54

Vágen T-G, Lal R, Singh BR. Soil carbon sequestration in sub-Saharan Africa: a review. Land Degrad Dev. 2005;16:53-71.

Vanderhaegen K, Verbist B, Hundera K, Muys B. REALU vs. REDD+: carbon and biodiversity in the Afromontane landscapes of SW Ethiopia. For Ecol Manag. 2015;343:22-33.

Walkley A, Black CA. An examination of digestion method for determining soil organic matter and proposed modification of the proposed chromic acid titration method. Soil Sci. 1934;37:29-38.

Wassie A, Sterck FJ, Teketay D, Bongers F. Effects of livestock exclusion on tree regeneration in church forests of Ethiopia. For Ecol Manag. 2009; 257:765-72. 
Workneh S. Land use changes and soil organic carbon and soil nitrogen in the Northwestern Highlands of Ethiopia. Vienna, Switzerland: MSc Thesis, University of Natural Resources and Applied Life Sciences; 2008. p. 65.

Yimer F, Alemu G, Abdelkadir A. Soil property variations in relation to exclosure and open grazing land use types in the Central Rift Valley area of Ethiopia. Environ Syst Res. 2015;4:17. https://doi.org/10.1186/s40068-015-0041-2.

Yimer F, Ledin S, Abdelkadir A. Soil organic carbon and total nitrogen stocks as affected by topographic aspect and vegetation in the Bale Mountains, Ethiopia. Geoderma. 2006;135:335-44.

Yohannes H, Soromessa T, Argaw M. Carbon stock analysis along altitudinal gradient in Gedo Forest: implications for forest management and climate change mitigation. Am J Environ Prot. 2015;4(5):237-44.

Ready to submit your research? Choose BMC and benefit from:

- fast, convenient online submission

- thorough peer review by experienced researchers in your field

- rapid publication on acceptance

- support for research data, including large and complex data types

- gold Open Access which fosters wider collaboration and increased citations

- maximum visibility for your research: over $100 \mathrm{M}$ website views per year

At BMC, research is always in progress.

Learn more biomedcentral.com/submissions 